\title{
Impacts of supplementing broiler diets with a powder mixture of black cumin, Moringa and chicory seeds
}

\author{
M. Arif ${ }^{1}$, Z. Hayat ${ }^{1}$, M.E. Abd El-Hack ${ }^{2 \#}$, M. Saeed ${ }^{3}$, H.M. Imran ${ }^{1}$, A.N. Alowaimer ${ }^{4}$, \\ I.M. Saadeldin ${ }^{4,6}$, A.E. Taha ${ }^{7} \&$ A.A. Swelum ${ }^{4,5 *}$ \\ ${ }^{1}$ Department of Animal Sciences, College of Agriculture, University of Sargodha 40100, Pakistan \\ ${ }^{2}$ Department of Poultry, Faculty of Agriculture, Zagazig University, Zagazig, 44511, Egypt \\ ${ }^{3}$ Department of Animal Nutrition, Cholistan University of Veterinary and Animal Sciences, Bhawalpur 63100, Pakistan. \\ ${ }^{4}$ Department of Animal Production, College of Food and Agriculture Sciences, King Saud University, P.O. Box 2460, \\ Riyadh 11451, Saudi Arabia \\ ${ }^{5}$ Department of Theriogenology, Faculty of Veterinary Medicine, Zagazig University, Zagazig, 44511, Egypt \\ ${ }^{6}$ Department of Physiology, Faculty of Veterinary Medicine, Zagazig University, Zagazig, 44511, Egypt \\ ${ }^{7}$ Department of Animal Husbandry and Animal Wealth Development, Faculty of Veterinary Medicine, Alexandria \\ University, Edfina 22758, Egypt
}

(Received 1 February 2019; Accepted 20 March 2019; First published online 22 June 2019)

\author{
Copyright resides with the authors in terms of the Creative Commons Attribution 4.0 South African License. \\ See: http://creativecommons.org/licenses/by/4.0/za \\ Condition of use: The user may copy, distribute, transmit and adapt the work, but must recognize the authors and \\ the South African Journal of Animal Science.
}

\begin{abstract}
The present study aimed at evaluating the effect of a phytogenic mixture in the diet on broiler production. A total of 400 day-old unsexed Cobb broiler chicks were randomly allotted to four treatment groups of 10 replications in a randomised design experiment. The phytogenic feed mixture (BMC) contained equal ratios of black cumin, Moringa oleifera and chicory seeds. The treatment groups were as follows: T1 was fed the basal diet, while T2, T3 and T4 were fed the basal diet supplemented with $0.2 \%, 0.4 \%$ or $0.6 \%$ of three BMC mixture, respectively. Results showed that increasing the dietary BMC level could be associated with a gradual but significant increase in body weight and improvement in the feed conversion ratio when compared with the control group. Broiler diets enriched with $0.4 \%$ to $0.6 \%$ of the BMC mixture reduced gut microbial count of coliforms, $E$. coli and $C$. perfringens as well as gut $\mathrm{pH}$, compared to the control group. Increasing the dietary BMC mixture level was associated with gradual but significant decrease in serum total cholesterol, low density lipoprotein concentrations and liver enzymes concentrations. However, there was an increase in the high density lipoprotein concentration, and glutathione peroxidase and superoxide dismutase activity in serum. In conclusion, the BMC mixture could be deemed an effective growth promoter, but further research is needed to evaluate it as a viable alternative to antibiotics.
\end{abstract}

Keywords: blood, broiler, carcass, microbiota, oxidative status, performance, phytogenic

\# Correspondence: m.ezzat@zu.edu.eg or dr.mohamed.e.abdalhaq@gmail.com; aswelum@ksu.edu.sa

\section{Introduction}

The term phytogenic compounds refer to the utilised parts (e.g. fruits, seeds, bark, roots and leaves) of various aromatic herbs and spices notably thyme, black cumin, anise, chicory, garlic, Moringa oleifera, rosemary, mustard, oregano and pepper (Abd El-Hack \& Alagawany, 2015; Alagawany \& Abd El-Hack, 2015; Abd El-Hack et al., 2016a). Aromatic plants and their essential oils are widely used for their antimicrobial action and stimulating effects on animal digestive systems (Wenk, 2003). Phytogenic compounds derive their beneficial properties from the content of bioactive molecules such as linalool, cineole, anethole, allicin, allyliso thiocyanate, capsaicin, carvacrol, piperine and thymol (Abd El-Hack et al., $2016 b ; 2016 c)$. However, more consideration should be given to the antibacterial and antioxidant properties of these compounds (Abd El-Hack et al., 2018). At present, there is more interest in using phytogenic additives in cosmetics, animal nutrition, pharmaceuticals and food meant for human consumption (Alagawany et al., 2017). Black cumin is widely grown in different parts of the world and its seeds have been used to improve health in various countries such as the Middle East and Southwest Asia. Several studies 
have confirmed that black cumin could enhance the growth and productive performance of poultry (Alagawany et al., 2017). Guler \& Ertas (2006) found that black cumin seed had great impact on the ratio of feed conversion to weight gain. Moringa oleifera belongs to the family of Moringaceae. It is an effective treatment for malnutrition. Moringa is a rich source of a variety of essential phytochemicals present in its seeds, pods and leaves (Gopalakrishnan et al., 2016).

Chicory plays a key role as an anti-inflammatory and antioxidant. It also has immunological, sedative, reproductive, anticancer, protozoal, cardiovascular, hypolipidemic, antidiabetic, gastro-protective, antimicrobial, anthelmintic and analgesic properties, without inducing therapeutic adverse effects (Saeed et al., 2017). It improves feed efficiency and immunity by minimising pathogenic microorganisms in the digestive tract (Saeed et al., 2017). Phytogenic compounds have significant potential as an alternative to antibiotic growth promoters and are generally accepted as an effective part of day-to-day animal nutrition. The objective of the study was to evaluate the effect of a mixture of black cumin, Moringa oleifera and chicory seeds on growth performance, carcass traits, caecal microbial count, blood chemistry and haematology in broiler chickens.

\section{Materials and Methods}

The present experiment was conducted at a Poultry Research Station, University College of Agriculture, University of Sargodha, Sargodha, Pakistan. All experimental procedures were carried out according to the Local Experimental Animal Care Committee and approved by the institutional ethics committee of the University College of Agriculture; University of Sargodha (AGSU-147017). The trial covered a period of six weeks.

A total of 400 day-old unsexed Cobb broiler chicks were randomly allotted to four treatment groups of 10 replicates (10 birds per replicate) in a randomised design. The experimental birds were reared in a floor litter system; a 2-inch layer of rice husk was used as bedding material, evenly spread throughout the pens. Feed (in mash form) and water were offered ad libitum throughout the experimental period. The birds were reared in ISO-managerial, hygienic, and sanitary conditions. The brooding temperature of $32{ }^{\circ} \mathrm{C}$ was gradually decreased to $26^{\circ} \mathrm{C}$ by the 3rd week of age, and the chicks were exposed to $23 \mathrm{~h}$ of light. Broiler chickens in all pens were vaccinated against Newcastle disease and infectious bronchitis (Nobilis ${ }^{\circledR}$ Ma5+Clone 30, Intervet, Boxmeer, Netherlands) on d 7; Gumboro Intermediate Plus (Bursine Plus ${ }^{\circledR}$ vaccine, Zoetis, NJ, USA) on d 14; and LaSota (Nobilis ${ }^{\circledR}$ ND LaSota, Intervet) on d $18 \mathrm{~d}$ of age. All vaccines were administered via eye drops. The chicks were kept under continuous lighting during the first two days after hatching, and thereafter $23 \mathrm{~h}$ light and one hour darkness per day.

Four iso-energetic and iso-nitrogenous diets were formulated to provide the nutrient requirements for broilers according to NRC (1994) recommendations. Composition and chemical analysis of the basal diets are shown in Table 1. The phytogenic mixture (BMC) used in this experiment contained the following: 1 part black cumin seeds, 1 part Moringa oleifera seeds and 1 part chicory seeds. Treatment groups were distributed as follows: $\mathrm{T}_{1}$ : control or basal diet; $\mathrm{T}_{2}$ : basal diet $+0.2 \% \mathrm{BMC}$ mixture; $\mathrm{T}_{3}$ : basal diet $+0.4 \%$ $\mathrm{BMC}$ mixture; $\mathrm{T}_{4}$ : basal diet $+0.6 \% \mathrm{BMC}$ mixture. The phytogenic additives were purchased from Faisal Traders (Sargodha, Pakistan).

The content of total phenolic compounds in Moringa, chicory, and Nigella sativa seed powders were analysed using the Folin-Ciocalteu procedure (Gurnani et al., 2016). In addition, total flavonoids were estimated according to Meda et al. (2005), as shown in Table 2.

Individual live body weight was recorded at 1, 3 and 6 weeks of age. The body weight gain of each chick was calculated during the experimental periods. Feed intake was recorded weekly on a replicate basis to estimate the feed conversion ratio (FCR) of feed intake $(\mathrm{g})$ : weight gain $(\mathrm{g})$. Birds were observed twice daily to record mortalities.

At the end of the experiment ( 6 weeks of age), three birds from each replicate were slaughtered and eviscerated after a $12 \mathrm{~h}$ starvation period, although with a continuous supply of water. The birds were weighed before slaughtering and again after evisceration to calculate dressing percentage. Also, the weights of internal organs (liver, gizzard, heart, spleen, bursa of Fabricius and abdominal fat) were recorded in addition to gut length. Carcasses were divided and the weights of thigh, breast and neck were measured.

At the end of the trial, three birds from each replicate were euthanized and the caecum was removed for further culture. Total counts of coliform, E. coli and C. perfringens, were done by membrane filter techniques, as described by Brantner et al. (1994). The caecum $\mathrm{pH}$ was determined using a digital $\mathrm{pH}$ meter (Apera Instruments MP511 Benchtop pH Meter). 
Table 1 Composition and chemical analysis of the basal diets (as fed)

\begin{tabular}{|c|c|c|}
\hline \multirow[b]{2}{*}{ Items } & \multicolumn{2}{|c|}{ Basal diets } \\
\hline & $\begin{array}{c}\text { Starter } \\
(1-3 \text { weeks) }\end{array}$ & $\begin{array}{c}\text { Finisher } \\
\text { (3 - } 6 \text { weeks) }\end{array}$ \\
\hline \multicolumn{3}{|l|}{ Ingredients (\%) } \\
\hline Yellow Corn & 57.13 & 60.53 \\
\hline Soybean meal & 31.65 & 27.15 \\
\hline Gluten meal & 6.50 & 6.10 \\
\hline Di Calcium phosphate & 1.70 & 1.50 \\
\hline Limestone & 1.24 & 1.15 \\
\hline Vitamin-mineral Premix ${ }^{\star}$ & 0.30 & 0.30 \\
\hline Salt & 0.30 & 0.30 \\
\hline DL Methionine & 0.05 & 0.02 \\
\hline L-Lysine & 0.13 & 0.10 \\
\hline Soybean oil & 1.00 & 2.85 \\
\hline Total & 100 & 100 \\
\hline \multicolumn{3}{|l|}{ Calculated analysis ${ }^{* *}:$} \\
\hline Crude protein $\%$ & 23.00 & 21.00 \\
\hline ME Kcal/kg diet & 2951 & 3099 \\
\hline Calcium \% & 1.00 & 0.90 \\
\hline Phosphorus (available) \% & 0.45 & 0.40 \\
\hline Lysine \% & 1.20 & 1.05 \\
\hline Methionine + Cystein \% & 0.83 & 0.74 \\
\hline Crude fibre $\%$ & 3.56 & 3.31 \\
\hline
\end{tabular}

* Growth vitamin and mineral premix: $2.5 \mathrm{~kg}$ contained:

Vitamin A $12000000 \mathrm{IU}$; vitamin $\mathrm{D}_{3}, 2000000 \mathrm{IU}$; vitamin. E. $10 \mathrm{~g}$; vitamin $\mathrm{K}_{3} 2 \mathrm{~g}$; vitamin $\mathrm{B}_{1}, 1000 \mathrm{mg}$; vitamin $\mathrm{B}_{2}, 49$ $\mathrm{g}$; vitamin $\mathrm{B}_{6}, 105 \mathrm{~g}$; vitamin $\mathrm{B}_{12}, 10 \mathrm{mg}$; pantothenic acid, $10 \mathrm{~g}$; niacin, $20 \mathrm{~g}$, folic acid, $1000 \mathrm{mg}$; biotin, $50 \mathrm{~g}$; choline chloride, 500 mg, Fe, 30 g; Mn, 40 g; Cu, 3 g; Co, 200 mg; Si, 100 mg and Zn , 45 g

** Calculated according to NRC (1994)

Table 2 Total phenolic and flavonoid compounds of black cumin, Moringa, and chicory seeds

\begin{tabular}{lccc}
\hline \multirow{2}{*}{ Items } & \multicolumn{3}{c}{ Seed powder of } \\
\cline { 2 - 4 } & Nigella sativa & Moringa & Chicory \\
\hline Total phenolics (mg GAE/g seeds) & 78.87 & 62.31 & 53.52 \\
Total flavonoids (mg QE/g seeds) & 39.96 & 15.74 & 31.33 \\
\hline
\end{tabular}

GAE: gallic acid equivalent; QE: querctin equivalent

Blood samples were randomly collected in sterilised tubes (10 samples per treatment) after slaughtering. Samples were left to coagulate and were centrifuged at $3500 \mathrm{rpm}$ for $15 \mathrm{~min}$ to obtain clear sera, and the serum samples were kept in Eppendorf tubes at $-20{ }^{\circ} \mathrm{C}$ for biochemical analysis. For haematological indices, five blood samples from each group were taken by sterile syringe containing anticoagulant (EDTA) and transferred to the laboratory for determination of red blood count (RBCs) using a haemocytometer. White blood cell (WBCs), packed cell volume (PCV) and haemoglobin concentration $(\mathrm{mg} / \mathrm{dL})$ were also determined. The alkaline phosphatase (AIP, EC 3.1.3.1), alanine amino transferase (ALT, EC 2.6.1.2), aspartate aminotransferase (AST, EC 2.6.1.1), glutathione peroxidase (GPx, EC 1.11.19) and superoxide dimutase (SOD, EC 1.15.1.1) activities, and glucose, calcium, phosphorus, total cholesterol, 
triglyceride, high density lipoprotein (HDL) and low density lipoprotein (LDL) concentrations in serum were determined spectrophotometrically using commercial diagnostic kits from Faisal Traders (Sargodha, Pakistan) (Akiba et al., 1982).

Data were subjected to analysis of variance (ANOVA) procedures appropriate for a completely randomised design using a statistical programme (SAS, 2001) to assess the significant differences using Duncan's multiple range testing.

\section{Results and Discussion}

The impact of the dietary BMC mixture on growth performance traits is shown in Table 3 . It is noticeable that all growth performance indices were significantly $(P<0.05)$ affected by dietary supplementation of BMC. Increasing the dietary BMC level was associated with a gradual decrease $(P<0.05)$ in total feed intake, increase $(P<0.05)$ in body weight gain and improvement $(P<0.05)$ in feed conversion ratio during the whole experimental period ( 1 - 6 week) and the intervals ( 1 - 3 and $3-6$ weeks), compared to the control group.

Table 3 Effect of dietary phytogenic feed (BMC) mixture supplementation on growth performance of broiler chickens

\begin{tabular}{|c|c|c|c|c|c|c|}
\hline Items (g) & $\mathbf{T}_{1}$ & $\mathbf{T}_{2}$ & $\mathbf{T}_{3}$ & $\mathbf{T}_{4}$ & SEM & $P$-value \\
\hline \multicolumn{7}{|c|}{ Total feed intake (g) } \\
\hline Starter (1-3 wk) & $1026.3^{\mathrm{a}}$ & $1025.4^{\mathrm{a}}$ & $1019.3^{b}$ & $1015.9^{b}$ & 14.90 & 0.0421 \\
\hline Finisher (3-6 wk) & $2033.1^{\mathrm{a}}$ & $1995.0^{b}$ & $1981.4^{c}$ & $1974.0^{d}$ & 17.20 & 0.0214 \\
\hline Total (1-6 wk) & $3059.4^{a}$ & $3020.4^{b}$ & $3000.7^{c}$ & $2989.9^{d}$ & 25.21 & 0.0152 \\
\hline \multicolumn{7}{|c|}{ Body weight gain (g) } \\
\hline Starter (1-3 wk) & $640.4^{\mathrm{C}}$ & $655.3^{b}$ & $675.1^{\mathrm{a}}$ & $677.0^{\mathrm{a}}$ & 8.87 & 0.0153 \\
\hline Finisher (3-6 wk) & $921.6^{\mathrm{d}}$ & 953.0 & $1023.6^{b}$ & $1157.1^{\mathrm{a}}$ & 9.93 & 0.0254 \\
\hline Total (1-6 wk) & $1562.0^{d}$ & $1608.3^{\mathrm{c}}$ & $1698.7^{b}$ & $1834.1^{\mathrm{a}}$ & 14.76 & 0.0331 \\
\hline \multicolumn{7}{|c|}{ Feed conversion ratio (g feed/g gain) } \\
\hline Starter (1-3 wk) & $1.60^{\mathrm{a}}$ & $1.56^{\mathrm{b}}$ & $1.51^{\mathrm{c}}$ & $1.50^{\mathrm{C}}$ & 0.48 & 0.0221 \\
\hline Finisher (3-6 wk) & $2.21^{\mathrm{a}}$ & $2.09^{b}$ & $1.94^{\mathrm{C}}$ & $1.71^{d}$ & 0.73 & 0.0154 \\
\hline Overall (1-6 wk) & $1.96^{\mathrm{a}}$ & $1.88^{b}$ & $1.77^{\mathrm{c}}$ & $1.63^{d}$ & 0.38 & 0.0412 \\
\hline
\end{tabular}

$\mathrm{T}_{1}$ : control or basal diet; $\mathrm{T}_{2}$ : basal diet $+0.2 \%$ BMC mixture; $\mathrm{T}_{3}$ : basal diet $+0.4 \% \mathrm{BMC}$ mixture; $\mathrm{T}_{4}$ : basal diet $+0.6 \%$ BMC mixture

BMC mixture contained 1 part black cumin seeds: 1 part Moringa oleifera seeds: 1 part chicory seeds

SEM: standard error of mean

Means in same row with no superscript or with common superscripts are not significantly different $(P<0.05)$

Improvement in body weight gain (Table 3) may be due to some compounds in the phytogenic additives that improve digestion and absorption of some nutrients. It may also be due to the presence of bioactive components causing greater feed utilisation resulting in improved growth. Aromatic black seeds have been used widely as a digestive stimulant (Gilani et al., 2004). The improvement in growth performance indices may also be attributed to the effects of the secondary components added to the BMC mixture (phenolic and flavonoid compounds). Alabi et al. (2017) reported that the flavonoid content of Moringa oleifera seeds had a positive effect on broiler growth rate due to the phenolic compounds of black seed oil (Attia \& Al-Harthi, 2015). Phytogenic additives can also reduce the serious environmental problem of bacterial resistance caused by the use of antibiotics as a growth promoter (Perić et al., 2009). Fotina et al. (2013) demonstrated that optimal antioxidant supplementation to broiler diets is important to maintain the best growth rate, immune-competence and meat quality. The active compounds in phytogenic additives are absorbed in the intestine and rapidly metabolised. These compounds stimulate changes in membrane dynamics and permeability characteristics and the synthesis of proteins associated with cytoskeletal function, resulting in an increase in the absorptive surface of the small intestine (Khajuria et al., 2002). The results of this trial are supported by those reported by Alagawany et al. (2017) who theorised that herbs such as Nigella sativa, Moringa and chicory could reduce the degradation of amino acids and hence render amino 
acid more available, which positively improve growth performance. In this context, Guler \& Ertas (2006) found that black cumin seeds showed a positive impact on the weight gain and feed conversion ratio in broilers.

Hassan et al. (2017) found decreased feed consumption due to supplementing broiler diets with Moringa oleifera seed meal. However, the same authors reported depressed weight gain as a response to the addition of Moringa oleifera seed meal. They attributed these negative results on weight gain to the phytate which is considered an anti-nutritional factor that may reduce the bioavailability of minerals and the digestibility of protein and starch (Thompson, 1993). Saeed et al. (2017) found that broiler fed cichoriumintybus statistically $(P<0.05)$ enhanced growth performance by improving feed digestibility and absorption through stimulating the jejunum histo-morphometry. This is in line with our results.

On the other hand, Marzoni et al. (2014) claimed that the addition of a mixture of natural herbs did not exert any influences on growth performance traits of broilers. Cho et al. (2014) also noticed that phytogenic additives as feed supplements had no significant impact on feed consumption, body weight gain or FCR, comparing to the control group.

The impact of dietary treatment on carcass traits is presented in Table 4. Only carcass, breast and bursa of Fabricius weights differed significantly $(P<0.05)$ owing to the phytogenic mixture supplementation. Supplementing the diet with a high level of BMC mixture $(0.6 \%$ of the diet) led to the highest $(P<0.05)$ carcass (1175 g) and breast (504.71 g) weights, compared to that of the control group and other BMC levels, while the heaviest bursa of Fabricius glands were found in broilers fed the T1 and T2 diets.

Table 4 Effect of supplementation of a dietary phytogenic feed (BMC) mixture on carcass characteristics and visceral organ weights of broiler chickens

\begin{tabular}{lcccccc}
\hline Items (g) & $\mathbf{T}_{\mathbf{1}}$ & $\mathbf{T}_{\mathbf{2}}$ & $\mathbf{T}_{\mathbf{3}}$ & $\mathbf{T}_{\mathbf{4}}$ & $\mathbf{S E M}$ & $\boldsymbol{P}$-value \\
\hline Carcass & $1139^{\mathrm{b}}$ & $1134^{\mathrm{b}}$ & $1143^{\mathrm{ab}}$ & $1175^{\mathrm{a}}$ & 11.42 & 0.0214 \\
Thigh & 172.9 & 175.6 & 173.7 & 178.4 & 2.33 & 0.6541 \\
Breast & $449.9^{\mathrm{b}}$ & $445.0^{\mathrm{b}}$ & $478.1^{\mathrm{ab}}$ & $504.7^{\mathrm{a}}$ & 9.18 & 0.0154 \\
Neck & 63.6 & 63.1 & 66.0 & 64.3 & 1.01 & 0.5478 \\
Abdominal fat & 3.07 & 3.09 & 2.79 & 2.76 & 0.12 & 0.6240 \\
Gizzard & 38.6 & 34.4 & 35.1 & 35.7 & 1.11 & 0.6587 \\
Heart & 9.25 & 9.29 & 9.30 & 9.30 & 0.22 & 0.8452 \\
Liver & 39.7 & 39.9 & 39.7 & 39.7 & 0.21 & 0.6672 \\
Spleen & 0.24 & 0.24 & 0.25 & 0.25 & 0.09 & 0.8051 \\
Bursa of Fabricius & $0.25^{\mathrm{a}}$ & $0.25^{\mathrm{a}}$ & $0.23^{\mathrm{b}}$ & $0.22^{\mathrm{b}}$ & 0.02 & 0.0312 \\
Gut length (cm) & 9.01 & 9.06 & 9.06 & 9.09 & 0.07 & 0.6478
\end{tabular}

$\mathrm{T}_{1}$ : control or basal diet; $\mathrm{T}_{2}$ : basal diet $+0.2 \% \mathrm{BMC}$ mixture; $\mathrm{T}_{3}$ : basal diet $+0.4 \% \mathrm{BMC}$ mixture; $\mathrm{T}_{4}$ : basal diet $+0.6 \%$ BMC mixture

BMC mixture contained 1 part black cumin seeds: 1 part Moringa oleifera seeds: 1 part chicory seeds

SEM: standard error of mean

Means in same row with no superscript or with common superscripts are not significantly different $(P<0.05)$

Our results are partially in accordance with those reported by Marzoni et al. (2014) who stated that the addition of a mixture of natural antioxidants did not exert any impact on the majority of broiler carcass traits. Cabuk et al. (2006) also investigated the influence of herb mixtures on weights of internal organ of broilers and they found no significant impact. Consistent with our findings, Alagawany et al. (2017) demonstrated that dietary herbal plants have a positive influence on the metabolism of protein and utilisation of nutrients which may positively reflect on breast weight. Molepo (2014) also reported that dietary Moringa seed addition increased the weight of broiler gizzards. However, Ayssiwede et al. (2010) found no improvement in carcass criteria due to Moringa seed meal inclusion in Senegal chicken diets. Ali (2011) reported that the addition of chicory seeds to broiler diets enhanced carcass traits.

As shown in Table 5, treating broiler diets with BMC mixture up to $4 \%-6 \%$ of the diet, reduced $(P$ $<0.05)$ the gut microbial count of coliforms, $E$. coli and $C$. perfringens, as well as gut $\mathrm{pH}$, compared to that of the control group. There was no significant difference between the control and $T_{1}$ groups. 
Table 5 Effect of supplementation of a dietary phytogenic feed (BMC) mixture on intestinal microbial count and $\mathrm{pH}$ in broiler chickens

\begin{tabular}{lcccccc}
\hline Items $\left(\log _{10} /\right.$ c.f.u) & $\mathbf{T}_{\mathbf{1}}$ & $\mathbf{T}_{\mathbf{2}}$ & $\mathbf{T}_{\mathbf{3}}$ & $\mathbf{T}_{\mathbf{4}}$ & SEM & P-value \\
\hline Coliforms & $10.52^{\mathrm{a}}$ & $10.53^{\mathrm{a}}$ & $8.06^{\mathrm{b}}$ & $8.07^{\mathrm{b}}$ & 2.02 & 0.0154 \\
E. coli & $8.90^{\mathrm{a}}$ & $8.90^{\mathrm{a}}$ & $7.09^{\mathrm{b}}$ & $7.09^{\mathrm{b}}$ & 1.03 & 0.0221 \\
C. perfringens & $5.98^{\mathrm{a}}$ & $5.98^{\mathrm{a}}$ & $4.16^{\mathrm{b}}$ & $2.15^{\mathrm{c}}$ & 1.04 & 0.0321 \\
Intestinal pH & $6.90^{\mathrm{a}}$ & $6.89^{\mathrm{a}}$ & $6.52^{\mathrm{b}}$ & $6.49^{\mathrm{b}}$ & 1.01 & 0.0412
\end{tabular}

$\mathrm{T}_{1}$ : control or basal diet; $\mathrm{T}_{2}$ : basal diet $+0.2 \%$ BMC mixture; $\mathrm{T}_{3}$ : basal diet $+0.4 \% \mathrm{BMC}$ mixture; $\mathrm{T}_{4}$ : basal diet $+0.6 \%$ BMC mixture

BMC mixture contained 1 part black cumin seeds: 1 part Moringa oleifera seeds: 1 part chicory seeds

SEM: standard error of mean

Means in same row with no superscript or with common superscripts are not significantly different $(P<0.05)$

Results of the present study showed a reduced gut microbial count as a result of a BMC mixture of up to $4 \%-6 \%$ (Table 5). Similarly, Alagawany et al. (2017) stated that herbs are a good source for reducing the pathogenic microbial population in the gastrointestinal tract. Ebru et al. (2008) claimed that black cumin produced bactericidal secretions which lowered the intestinal $\mathrm{pH}$ resulting in a reduction in the total count of harmful bacteria ( $E$. coli and salmonella) in quails. Ismail (2011) confirmed that black cumin supplementation to the quail diet reduced the quantity of $E$. coli and $C$. perfringens and reduced the total intestinal bacterial count in quail. Aruna \& Srilatha (2012) reported on the antibacterial properties of Moringa oleifera seed powder when used in water purification systems. Saeed et al. (2017) confirmed that chicory seed powder has a strong antimicrobial impact as a supplement to broiler diets.

The composition levels in blood are always indicative of the health status of the bird. None of the studied blood biomakers were significantly impacted by the dietary treatment; excluding blood glucose, total cholesterol, HDL and LDL (Table 6). Birds fed the $\mathrm{T}_{2}$ diet recorded the highest $(P<0.01)$ concentration $(24.29$ $\mathrm{mg} / \mathrm{dL}$ ) of blood glucose in comparison with the control group and other BMC mixture levels. No significant difference in the blood glucose level was found between the control and $T_{3}$ and $T_{4}$ groups. The increased dietary level of the BMC mixture was associated with the gradual decrease $(P<0.05)$ in serum total cholesterol and LDL concentrations, and the increase $(P=0.0212)$ in blood HDL level.

Increasing the dietary BMC mixture was accompanied by a gradual depression in serum total cholesterol and LDL concentations, and an elevation in serum HDL. Declining serum cholesterol and LDL concentrations could be due to minimising microbial intracellular pH (Abdo \& Zeinb, 2004). Microbial enzyme inhibition forces bacterial cell membranes to use energy to release acidic protons which led to a decline in intracellular pH (Aruna \& Srilatha, 2012). Consistent with our results, Ali et al. (2014) observed decreased blood LDL concentration in broilers fed a diet supplemented with $0.5 \%$ black cumin. These authors added that increasing the level of black cumin up to $0.75 \%$ elevated the serum concentration of HDL. Lotosh (1991) found that the glucose level was statistically increased by supplementing broiler diets with black cumin seed powder. As far as the impact on serum lipids is concerned, Hassan \& Yousef (2010) postulated that chicory supplementation lowered the total lipids and cholesterol in rats. Safamehr et al. (2013) also found that the reduced levels of serum cholesterol and abdominal fat in broilers were attributed to beta fructans derived from the chicory plant.

Results of the impact of BMC mixtures on liver enzymes and oxidative status were, judged by normal standards, unique (Table 7). A gradual depression $(P<0.05)$ in the activities of ALP, AST and ALT as well as gradual elevations $(P<0.05)$ in activities of GPx and SOD were observed as the level of BMC mixture increased; notably the activity of GPx and SOD, by removing reactive oxygen species. Saeed et al. (2017) confirmed the ability of chicory to reduce some biochemical indices such as ALP, AST and ALT. According to Noreen (2009), the anti-hepatotoxic properties of chicory extracts reduced activities of liver enzymes such as AST, ALP and ALT. The hepatoprotective role of adding chicory and celery leaves to a barley-based diet on hyper cholesterolemic rats was noted by Abd El-Mageed (2011). Marzouk et al. (2011) mentioned that chicory extract is rich in natural antioxidants and has the ability to reduce acetaminophen-induced hepatic damage through improving antioxidant indices such as the activity of GPX and SOD via its free radical scavenging properties. Gilani et al. (1998) reported the protective effect of the phenolic compound of chicory extract (esculetin) and its role in the reduction of $\mathrm{CCl} 4$ - and paracetamol-induced hepatic injury. The phenolic 
compounds of Moringa oleifera oils had antioxidant activity; and this is attributed to their important role in neutralising and absorbing free radicals (Basuny \& Al-Marzouq, 2016).

Table 6 Effect of supplementation of a dietary phytogenic feed dietary (BMC) mixture on serum chemistry and blood hematology in broiler chickens

\begin{tabular}{lcccccc}
\hline Items & $\mathbf{T}_{\mathbf{1}}$ & $\mathbf{T}_{\mathbf{2}}$ & $\mathbf{T}_{\mathbf{3}}$ & $\mathbf{T}_{\mathbf{4}}$ & $\mathbf{S E M}$ & $\boldsymbol{P}$-value \\
\hline Glucose $(\mathrm{mg} / \mathrm{dL})$ & $235.9^{\mathrm{b}}$ & $241.3^{\mathrm{a}}$ & $235.9^{\mathrm{b}}$ & $236.6^{\mathrm{b}}$ & 10.01 & 0.0024 \\
Calcium (mg/dL) & 10.77 & 10.81 & 10.80 & 10.757 & 3.05 & 0.8231 \\
Phosphorus (mg/dL) & 6.642 & 6.41 & 6.628 & 6.585 & 1.10 & 0.8792 \\
Total cholesterol (mg/dL) & $119.1^{\mathrm{a}}$ & $118.3^{\mathrm{ab}}$ & $116.9^{\mathrm{ab}}$ & $115.9^{\mathrm{b}}$ & 15.64 & 0.0321 \\
Triglycerides (mg/dL) & 119.0 & 118.9 & 119.6 & 119.4 & 3.59 & 0.8850 \\
HDL (mg/dL) & $57.1^{\mathrm{b}}$ & $57.9^{\mathrm{ab}}$ & $58.6^{\mathrm{ab}}$ & $60.1^{\mathrm{a}}$ & 8.75 & 0.0212 \\
LDL-(mg/dL) & $49.4^{\mathrm{a}}$ & $49.1^{\mathrm{ab}}$ & $47.0^{\mathrm{bc}}$ & $46.3^{\mathrm{c}}$ & 7.56 & 0.0332 \\
Hemoglobin (mg/dL) & 10.42 & 10.21 & 10.50 & 10.88 & 2.18 & 0.5481 \\
Red blood cells $\left(10^{6} / \mathrm{hL}\right)$ & 2.48 & 2.48 & 2.41 & 2.48 & 0.02 & 0.6332 \\
White blood cells $\left(10^{3} / \mathrm{\mu L}\right)$ & 2.17 & 2.15 & 2.08 & 2.12 & 0.08 & 0.5887 \\
PCV (\%) & 32.77 & 32.81 & 32.80 & 32.75 & 9.05 & 0.3845
\end{tabular}

$\mathrm{T}_{1}$ : control or basal diet; $\mathrm{T}_{2}$ : basal diet $+0.2 \%$ BMC mixture; $\mathrm{T}_{3}$ : basal diet $+0.4 \% \mathrm{BMC}$ mixture; $\mathrm{T}_{4}$ : basal diet $+0.6 \%$ BMC mixture

BMC mixture contained 1 part black cumin seeds: 1 part Moringa oleifera seeds: 1 part chicory seeds

HDL: high density lipoprotein, LDL: low density lipoprotein, PCV: packed cell volume

SEM: Standard error of mean

Means in same row with no superscript or with common superscripts are not significantly different $(P<0.05)$

Table 7 Effect of supplementation of a dietary phytogenic feed dietary (BMC) mixture on liver enzyme activities in serum and serum oxidative status in broiler chickens

\begin{tabular}{lcccccc}
\hline Items & $\mathrm{T}_{\mathbf{1}}$ & $\mathrm{T}_{\mathbf{2}}$ & $\mathrm{T}_{\mathbf{3}}$ & $\mathrm{T}_{4}$ & SEM & P-value \\
\hline $\operatorname{ALP}((\mu / \mathrm{L})$ & $56.14^{\mathrm{a}}$ & $55.43^{\mathrm{ab}}$ & $54.14^{\mathrm{bc}}$ & $53.57^{\mathrm{c}}$ & 8.44 & 0.0114 \\
$\operatorname{ALT}(\mu / \mathrm{L})$ & $21.14^{\mathrm{a}}$ & $20.43^{\mathrm{a}}$ & $18.57^{\mathrm{b}}$ & $18.14^{\mathrm{b}}$ & 2.40 & 0.0412 \\
$\operatorname{AST}(\mu / \mathrm{L})$ & $76.14^{\mathrm{a}}$ & $75.53^{\mathrm{a}}$ & $73.00^{\mathrm{b}}$ & $72.29^{\mathrm{b}}$ & 7.44 & 0.0214 \\
$\operatorname{GPx}(\mathrm{U} / \mathrm{L})$ & $207.79^{\mathrm{c}}$ & $209.57^{\mathrm{bc}}$ & $213.57^{\mathrm{ab}}$ & $216.57^{\mathrm{a}}$ & 12.06 & 0.0140 \\
$\operatorname{SOD}(\mathrm{U} / \mathrm{L})$ & $173.50^{\mathrm{c}}$ & $174.86^{\mathrm{bc}}$ & $178.29^{\mathrm{ab}}$ & $181.14^{\mathrm{a}}$ & 10.07 & 0.0020 \\
\hline
\end{tabular}

$\mathrm{T}_{1}$ : control or basal diet; $\mathrm{T}_{2}$ : basal diet $+0.2 \% \mathrm{BMC}$ mixture; $\mathrm{T}_{3}$ : basal diet $+0.4 \% \mathrm{BMC}$ mixture; $\mathrm{T}_{4}:$ basal diet $+0.6 \%$ BMC mixture.

BMC mixture contained 1 part black cumin seeds: 1 part Moringa oleifera seeds: 1 part chicory seeds.

ALP: alkaline phosphate, ALT: alanine amino transferase, AST: aspartate amino transferase, GPx: glutathione peroxidase, SOD: superoxide dismutase

SEM: Standard error of mean.

Means in same row with no superscript or with common superscripts are not significantly different $(P<0.05)$

\section{Conclusions}

The findings of this trial show that a supplementary mixture containing equal parts of black cumin, Moringa and chicory seeds and the synergistic effect of their major components of phenolics and flavonoid compounds, improved the growth performance of broilers by decreasing the microbial count and blood cholesterol, and by improving the oxidative effect. It could be concluded that this herb mixture could be used as an effective growth promoter, but further research is needed to evaluate it as an alternative to antibiotics. The recommended level is $0.6 \% \mathrm{BMC}$ mixture $/ \mathrm{kg}$ of broiler diet. 


\section{Acknowledgements}

The authors extended their appreciation to the Deanship of Scientific Research at King Saud University for funding this work through the research group project (\# RG-1438-066).

\section{Authors' Contributions}

$\mathrm{MA}, \mathrm{ZH}, \mathrm{HMI}$, and MS designed the study plan, collected literature, and drafted the manuscript. MEAEH, AS, IMS provided the technical help in the compilation of this manuscript. ANA, AET and MEAEH reviewed the manuscript and performed the final check. All the authors read and approved the final manuscript.

\section{Conflict of interest}

No potential conflict of interest was reported by the authors.

\section{References}

Abd El-Hack, M.E. \& Alagawany, M., 2015. Performance, egg quality, blood profile, immune function, and antioxidant enzyme activities in laying hens fed diets with thyme powder. J. Anim. Feed Sci. 24, 127-133.

Abd El-Hack, M.E., Alagawany, M., Farag, M.R., Tiwari, R., Karthik, K. \& Dhama, K., 2016a. Nutritional, healthical and therapeutic efficacy of black cumin (Nigella sativa) in animals, poultry and humans. Int. J. Pharmacol. 12, 232-248.

Abd El-Hack, M.E., Alagawany, M., Saeed, M., Arif, M., Arain, M.A., Bhutto, Z.A. \& Fazlani, S.A., 2016b. Effect of gradual substitution of soybean meal by Nigella sativa meal on growth performance, carcass traits and blood lipid profile of growing Japanese quail. J. Anim. Feed Sci. 25, 244-249.

Abd El-Hack, M.E., Alagawany, M., Ragab Farag, M., Tiwari, R., Karthik, K., Dhama, K., Zorriehzahra J. \& Adel, M., 2016c. Beneficial impacts of thymol essential oil on health and production of animals, fish and poultry: a review. J. Essen. Oil Res. 28(5), 365-382.

Abd El-Hack, M.E., Attia, A.I., Arif, M., Soomro, R.N. \& Arain, M.A., 2018. The impacts of dietary Nigella sativa meal and Avizyme on growth, nutrient digestibility and blood metabolites of meat-type quail. Anim. Prod. Sci. 58, 291-298, DOI:10.1071/AN16226.

Abd El-Mageed, M.N., 2011. Hepatoprotective effect of feeding celery leaves mixed with chicory leaves and barley grains to hypercholesterolemic rats. Mag. Pharm. 7, 151-156. DOI.org/10.4103/0973-1296.80675

Abdo, M. \& Zeinb A., 2004. Efficacy of acetic acid in improving the utilization of low protein-low energy broiler diets. Egypt Poult. Sci. 24, 123-141.

Akiba, Y., Jensen, L.S., Bart, C.R. \& Kraeling, R.R., 1982. Plasma estradiol, thyroid hormones and liver lipids determination in birds. J. Nutr. 112, 299-308.

Alabi, O.J., Malik, A.D., Ng'ambi, J.W., Obaje, P. \& Ojo, B.K., 2017. Effect of Aqueous Moringa oleifera (Lam) Leaf Extracts on Growth Performance and Carcass Characteristics of Hubbard Broiler Chicken. Rev. Bras. Cienc. Avic. 19, 273-280.

Alagawany, M., Abd El-Hack, M.E., Arain, M.A. \& Arif, M., 2017. Effect of some phytogenic additives as dietary supplements on performance, egg quality, serum biochemical parameters and oxidative status in laying hens. Indian J. Anim. Sci. 87, 103-110.

Alagawany, M. \& Abd El-Hack, M.E., 2015. The effect of rosemary herb as a dietary supplement on performance, egg quality, serum biochemical parameters, and oxidative status in laying hens. J. Anim. Feed Sci. 24, 341-347.

Ali, A., 2011. Effect of different levels of Chicory cichoriumintybus L., Zizaphora zizaphoratenuior L., nettle Urticadioica L. and Savoury saturejahortensis L. medicinal plants on carcass characteristics of male broilers. J. Med. Plants Res. $5,4354-4359$.

Ali, O.A.A., Suthama, N. \& Mahfudm, L.D., 2014. The effect of feeding black cumin Nigella Sativa. and vitamin c on blood lipid profiles and growth performance of broilers. Int. Ref. J. Engin. Sci. 3, 28-33.

Aruna M. \& Srilatha N., 2012. Water clarification using Moringaoleifera Lam. seed as a natural coagulant. Current Biotica. 5, 472-486.

Attia, Y.A., \& Al-Harth, M.A., 2015. Nigella sativa seed oil as an alternative to antibiotic growth promoters for broiler chickens. Eur. Poult. Sci. 79, 1-12, 2015.

Ayssiwede, S.B., Dieng, A., Chrysostome, C., Ossebi, W., Hornick, J.L. \& Missohou, A., 2010. Digestibility and metabolic utilization and nutritional value of Leucaenaleucocephala Lam. leaves meal incorporated in the diets of indigenous Senegal chickens. Int. J. Poult. Sci. 9, 767-776. DOI.org/10.3923/ijps.2010.767.776

Basuny, A.M. \& Al-Marzouq, M.A., 2016. Biochemical studies on Moringa oleifera seed oil. MOJ Food Process Technol. 2, 40-46

Brantner, A., Pfeiffer, K.P. \& Brantner, H., 1994. Applicability of diffusion methods required by the pharmacopoeias for testing antibacterial activity of natural compounds. Pharmazie. 49, 512-6.

Cabuk, M., Bozkurt, M., Alcicek, A., Akbas, Y. \& Kucukyilmaz, K., 2006. Effect of a herbal essential oil mixture on growth and internal organ weight of broilers from young and old breeder flocks. S. Afr. J. Anim. Sci. 36, 135-141. DOl.org/10.4314/sajas.v36i2.3996

Cho, J.H., Kim, H.J. \& Kim, I.H., 2014. Effects of phytogenic feed additive on growth performance, digestibility, blood metabolites, intestinal microbiota, meat color and relative organ weight after oral challenge with Clostridium perfringens in broilers. Livest. Sci. 160, 82-88. DOI.org/10.1016/j.livsci.2013.11.006

Ebru, U., Burak, U., Yusuf, S., Reyhan, B., Arif, K., Faruk, T.H., Emin, M., Aydin, K., Atilla, I.I., Semsettin, S. \& Kemal, E., 2008. Cardioprotective effects of Nigella sativa oil on cyclosporine A-induced cardio toxicity in rats. Basic Clin. Pharmacol. Toxicol. 103, 574-580. 
Fotina, A.A., Fisinin, V.I. \& Surai, P.F., 2013. Recent developments in usage of natural antioxidants to improve chicken meat production and quality. Bulgarian J. Agric. Sci. 19, 889-896.

Gilani, A.H., Janbaz, K.H. \& Shah, B.H., 1998. Esculetin prevents liver damage induced by paracetamol and CCl4. Pharmacol. Res. 37, 31-35.

Gilani, A.H., Jabeen, Q. \& Khan, M.A.U., 2004. A review of medicinal uses and pharmacological activities of Nigella sativa. Pak. J. Biol. Sci. 7, 441-451.

Gopalakrishnan, L., Doriya, K. \& Kumar, D.S., 2016. Moringa oleifera: A review on nutritive importance and its medicinal application. Food Sci. Human. Welln. 5, 49-56. DOI.org/10.1016/j.fshw.2016.04.001

Guler, T.B. \& Ertas, O.N., 2006. The effect of dietary black cumin seeds Nigella Sativa L. on the performance of broilers. Asian-Austral. J. Anim. Sci. 19, 425-430. DOI.org/10.5713/ajas.2006.425

Gurnani, N., Gupta, M., Mehta, D. \& Mehta, B.K., 2016. Chemical composition, total phenolic and flavonoid contents, and in vitro antimicrobial and antioxidant activities of crude extracts from red chilli seeds (Capsicum frutescens I.). J. Taibah Univ. Sci. 10, 462-470.

Hassan, H.A. \& Yousef M.I., 2010. Ameliorating effect of chicory Cichoriumintybus L. supplemented diet against nitrosamine precursors-induced liver injury and oxidative stress in male rats. J. Food Chem. Toxicol. 48, 21-63. DOI.org/10.1016/j.fct.2010.05.023

Hassan, U.K., Khalique, A., Pasha, T.N., Akram, M., Mahmood, S., Sahota, A., Imran, M.S. \& Saleem, G., 2017. Influence of Moringa oleifera decorticated seed meal on broiler performance and immunity. Pakistan Vet. J. 37, 47-50.

Ismail, Z.S.H., 2011. Effects of dietary black cumin growth seeds Nigella sativa L or its extract on performance and total coliform bacteria count on broiler chicks. Egypt Poult. Sci. 31, 139-149.

Khajuria, A., Thusu, N. \& Zutshi, U., 2002. Piperine modulates permeability characteristics of intestine by inducing alterations in membrane dynamics: influence on brush border membrane fluidity, ultrastructure and enzyme kinetics. Phytomed. 9, 224-231. DOI.org/10.1078/0944-7113-00114

Lotosh, T.D., 1991. Experimental bases and prospects for the use of humic acid preparations from peat in medicine and agricultural production. Nauchnye Doki. Vyss. Shkoly. Biol.Nauki. 10, 99-103.

Marzouk, M., Sayed, A.A. \& Soliman, A.M., 2011. Hepatoprotective and antioxidant effects of Cichorium endivia L. leaves extract against acetaminophen toxicity on rats. J. Med. Med. Sci. 2, 1273-1279.

Marzoni, M., Chiarini, R., Castillo, A., Romboli, I., De Marco, M. \& Schiavone, A., 2014. Effects of dietary natural antioxidant supplementation on broiler chicken and Muscovy duck meat quality. Anim. Sci. Paper Rep. 32 , 359-368.

Meda, A., Lamien, C.E., Romito, M., Millogo, J. \& Nacoulma, O.G., 2005. Determination of the total phenolic, flavonoid and proline contents in burkina fasan honey, as well as their radical scavenging activity. Food Chem. 91, 571-577

Molepo, L.S., 2014. Effect of Moringa seed meal supplementation on productivity and carcass characteristics of ross 308 broiler chickens. PhD dissertation. University of Limpopo.

Noreen, S., 2009. Antihepatotoxic effects of Cichoriumintybus Kasni. seeds against liver damage induced by carbon tetrachloride and paracetmol in broiler chicks, MSc. Thesis. Dept. Vet.Clinical Medicine, Univ. Agri. Faisalabad, Pakistan.

NRC., 1994. Nutrient Requirements of Poultry. National Academy Press, Washington, DC. DOI.org/10.17226/2114

Perić, L., Žikić, D. \& Lukić, M., 2009. Application of alternative growth promoters in broiler production. Biotech. Anim. Husb. 25, 387-397. DOI.org/10.2298/bah0906387p

Saeed, M., Abd El-Hack, M.E., Alagawany, M., Arain, M.A., Arif, M., Mirza, M.A., Naveed, M., Chao, S., Sarwar, M., Sayab, M. \& Dhama, K., 2017. Chicory Cichorium intybus. Herb: chemical composition, pharmacology, nutritional and healthical applications. Int. J. Pharmacol. 13, 351-360. DOI.org/10.3923/ijp.2017.351.360

Safamehr, A., Fallah, F. \& Nobakht, A., 2013. Growth performance and biochemical parameters of broiler chickens on diets consist of chicory Cichoriumintybus. and nettle Urticadioica. with or without Multi-Enzyme. Iranian J. Appl. Anim. Sci. 3, 131-137.

SAS Institute Inc., 2001. SAS User's Guide.Release 8.2. SAS Institute Inc, Cary, NC.

Thompson, L.U., 1993. Potential health benefits and problems associated with anti-nutrients with foods. Food Res. Int. 26,131-49. DOI.org/10.1016/0963-996993.90069-u

Wenk, C., 2003. Herbs and botanicals as feed additives in monogastric animals. Asian-Austral. J. Anim. Sci. 16, 282-289. 